\title{
Husband's Support for Pregnant Women Facing Childbirth at Kalasan Public Health Center, Sleman, Indonesia
}

\author{
$1^{\text {st }}$ Sartika Dwi Yolanda Putri \\ Midwifery Program \\ Universitas Aisyiyah Yogyakarta \\ Yogyakarta, Indonesia \\ dwisartika66@gmail.com
}

\author{
$* 2^{\text {nd }}$ Nurul Kurniati \\ Midwifery Program \\ Universitas Aisyiyah Yogyakarta \\ Yogyakarta, Indonesia \\ nurul.kurniati@unisayogya.ac.id
}

\begin{abstract}
Maternal Mortality Rate (MMR) in Indonesia was 305 deaths per 100,000 live births in 2017. Prolonged labor is one of the causes of high MMR in Indonesia. Several factors contribute to long labor, including power, passage, passanger and psychological. Psychological mothers who are not ready to face childbirth or excessive anxiety, worry and fear without cause so that ultimately it leads to anxiety disorders. One effort to overcome the negative effects of anxiety is the support of husband or family. The purpose of this study is to describe the support of husband for mothers at Kalasan Public Health Center in Sleman Regency. This research method uses quantitative research design using analytical survey with cross sectional approach. The population is 109 pregnant women. The total sample of 33 respondents by taking $30 \%$ of the total population. The sampling technique used accidental sampling. Data collecting in this research use quesioner about support husband for mother and data analysis using univariate analysis. Based on the results of the study, respondents who received good support from their husbands were $60,6 \%$ and $39,4 \%$ get not enough support from the husband. It is hoped that the husband will participate in empathy and provide the best support since pregnancy, until the delivery and postpartum period to reduce the anxiety of pregnant women in the face of childbirth.
\end{abstract}

Keywords - husband support, pregnant women, childbirth

\section{INTRODUCTION}

Pregnancy and childbirth are physiological events, but these natural processes can deviate until they become pathological, because all individuals are at risk of pathological events. The emotions of a woman during pregnancy will be different from the period before pregnancy. Women tend to be sensitive during pregnancy, especially in the third trimester and will gradually drop to normal levels between 6-8 weeks post-partum so that preparation for delivery is needed [1].

According to [2], mothers who are not prepared to give birth will be more anxious and show fear in a silent behavior to cry, even though birth events are normal physiological phenomena, in fact the process of pregnancy and childbirth leads to many complications even good death mother or baby. According to WHO (World Health Organization), Maternal Mortality Rate (MMR) in 2015 amounted to 239 per 100,000 live births (KH) [3]. Based on the results of the
2015 Intercensal Population Survey (SUPAS), MMR in Indonesia showed 305 maternal deaths per 100,000 KH [4]). Based on data (Yogyakarta Health Office, 2017) in 2017 MMR as many as 34 cases. This shows that the maternal mortality rate in Indonesia is still very high.

According to Agustina, $85 \%$ of maternal deaths due to pregnancy and birth complications can be avoided by providing care, protection and assistance that are both jointly and integrated between families, especially husbands, communities, health workers and the government [5]. According to Nevid, family support is an important factor in fending off the negative effects of anxiety [6].

In an effort to accelerate the reduction of MMR, in 2012 the Ministry of Health launched the Expanding Maternal and Neonatal Survival (EMAS) program which is expected to reduce maternal and neonatal mortality rates by $25 \%$. The program seeks to reduce maternal mortality and neonatal mortality by increasing the quality of emergency obstetric and newborn care services in at least 150 PONEK Hospitals and 300 public health center PONED) and 2) strengthening an efficient and effective referral system between puskesmas and hospitals [4]. With this program it is expected that all pregnant women can be helped in the process of childbirth, including efforts to reduce anxiety in the face of childbirth.

Based on a preliminary study in Sleman Regency in 2018 there were 1051 pregnant women and 156 pregnant women included in the Kalasan Pusesmas area and there were 23 pregnant women who experienced pregnancy complications so that they needed support in facing the delivery process later from health workers, husbands and families. The government is paying attention to efforts to increase the role of men, namely by promoting the Please do not give the page number in the header or footer. standby husband program (husbands ready to take care). The husband must know the development of his wife's condition, give encouragement and enthusiasm and pay more attention. Mothers who were accompanied during labor gave many advantages including reducing cesarean section $(50 \%)$, shorter delivery time $(25 \%)$, decreasing epidual delivery $(60 \%)$, reducing oxytocin use $(40 \%)$, decreasing analgesic administration $(30 \%) \%$ ) and reduce birth by forcep $(40 \%)$ (Indonesian Ministry of Health, 2017). Based on this, this study aims to 
describe the husband's support for mothers in the face of childbirth

\section{METHOD}

The design of this research uses quantitative research design with analytic survey research method with cross sectional time approach [7]. The population in this study were all third trimester pregnant women are 109 mothers. The sampling method using the accidental sampling technique was 33 pregnant women in accordance with the provisions if the subjects of more than 100 respondents were set to be $20-25 \%$

Data collection was carried out using a questionnaire consisting of 17 statements that included items of emotional support, instrumental support, assessment support, and information support of the husband to the mother. Kuesionerv has tested the validity and reliability of 20 respondents with the same respondent characteristics by Widiarti (2017) [8] with the product moment test results $r$ count> 0.44 and the Cronbach $r$ alpha count value is greater than the constant> 0.06 which is the value of $r 0.866$. The measurement results category of husband's support by setting the mean value are as follows With the supporting category: score mean mean value and less support: score <mean value with a number of statements of 17 pieces with answer choices highest value of 68 and lowest of 17, while mean value of 34

The results of measuring husband's support are categorized as follows:

- $\quad$ Supports, if the score is $\geqslant$ mean

- Not supportive, if the score <mean

The data obtained were then performed univariate analysis by looking at the frequency distribution of the picture of support provided by the husband to the mother in the face of childbirth.

\section{RESULT}

The results of the study showed the following results:

\section{A. Husband support in general to mothers facing childbirth}

The data shows general husband support for mothers as follows:

TABLE I. FREQUENY DISTRIBUTION OF HUSBAND's SUPPORT TO MAOTEHRS FASCING CHILDBIRTH

\begin{tabular}{|c|c|c|}
\hline Husband's & Frequency & Percentage \\
\hline Support & & $\%$ \\
\hline Support & 20 & 60,6 \\
\hline Less Support & 13 & 39,4 \\
\hline Total & 33 & 100 \\
\hline
\end{tabular}

Based on table 4.2 it can be seen that of the total respondents numbering 33 trimester III pregnant women, there were $60.6 \%$ received husband support and $39.4 \%$ lacked husband support.

\section{B. Husband's Support in the form of Assessment support}

The description of the distribution of respondents' answers to the husband's support variable questions in the form of assessment support:

TABLE II. FREQUENCY DISTRIBUTION OF SUPPORT FORMS FOR HUSBAND ASSESSMENT IN PREGNANT WOMEN

\begin{tabular}{lcc}
$\begin{array}{c}\text { Husband's } \\
\text { Support }\end{array}$ & $\begin{array}{c}\text { Frequency } \\
\text { F }\end{array}$ & $\begin{array}{c}\text { Percentage } \\
\text { \% }\end{array}$ \\
\hline Support & 21 & 63,6 \\
Less Support & 12 & 36,4 \\
& & \\
Total & $\mathbf{3 3}$ & $\mathbf{1 0 0}$ \\
\hline
\end{tabular}

Based on table 3 it can be seen that $63.6 \%$ received husband support in the form of assessment support, while $36.4 \%$ lacked husband support in the form of assessment.

\section{Husband's support in the form of Instrumental support}

The description of the respondent's answer to the statement of husband's support variable in the form of instrumental support:

TABLE III. FREQUENCY DISTRIBUTION OF HUSBAND'S INSTRUMENTAL SUPPORT FORMS TO MOTHERS

\begin{tabular}{lcc}
\hline $\begin{array}{c}\text { Husband's } \\
\text { Support }\end{array}$ & $\begin{array}{c}\text { Frequency } \\
\text { F }\end{array}$ & $\begin{array}{c}\text { Percentage } \\
\text { \% }\end{array}$ \\
\hline Support & 23 & 69,7 \\
Less Support & 10 & 30,3 \\
Total & $\mathbf{3 3}$ & $\mathbf{1 0 0}$
\end{tabular}

Based on table 4.5 it can be seen that $69.7 \%$ received husband support in the form of instrumental support, while $30.3 \%$ lacked husband support in the form of instrumental support.

\section{Husband Support in the form of information support}

The distribution of respondents' answers to the husband's support variable statement in the form of information support:

TABLE IV. FREQUENCY DISTRIBUTION OF HUSBAND INFORMATION SUPPORT FORMS FOR PREGNANT WOMEN

\begin{tabular}{lcc}
\hline $\begin{array}{c}\text { Husband's } \\
\text { Support }\end{array}$ & $\begin{array}{c}\text { Frequency } \\
\text { F }\end{array}$ & $\begin{array}{c}\text { Percentage } \\
\text { \% }\end{array}$ \\
\hline Support & 18 & 54,5 \\
Less Support & 15 & 45,5 \\
Total & 33 & 100 \\
\hline
\end{tabular}

Based on table 5 it can be seen that $54.5 \%$ received husband support in the form of information support, while $45.5 \%$ lacked husband support in the form of information support. 


\section{DISCUSSION}

\section{A. Husband support in general to mothers facing childbirth}

Based on the results of the study showed the husband's support for pregnant women in the third trimester in the face of childbirth which received husband support as much as $60.6 \%$ and $39.4 \%$ lacked husband support. Family support is the single most vital resource in fighting anxiety, such as support that comes from a husband [9].

The involvement of the husband or partner in supporting pregnancy and antenatal care is still low. Likewise, based on this study, it was found that $39.4 \%$ were less supportive. To increase the support and involvement of the husband in the birth plan to overcome cultural barriers and the role of health workers and health facility policies on family labor is the most important thing [10].

Husband support to pregnant women to prepare for labor is needed. In this case the husband is very active role in motivating pregnant women to check their pregnancy health workers to get services that are according to standards (Sumiati, 2015). Other support is also in the form of assisting the wife during antenatal visits, giving more attention and affection when the wife is pregnant, providing additional information on important matters in caring for pregnancy and providing a means of both costs and transportation to conduct antenatal care.

\section{B. Husband Support in the form of Emotional support}

The husband's emotional support for his wife can cause inner peace and a happy feeling in his wife, so that the wife finally becomes easy to adjust to the situation of the pregnancy [12].

Husband support is the attitude, act of acceptance of family or husband towards family members (mothers) in the form of emotional support, assessment, instrumental and information support [13]. Much evidence is shown that women who are watched and loved by their partners during pregnancy will show fewer emotional and physical symptoms [14].

The intended form of emotional support is empathy, love and trust from others, especially husband as motivation. The husband functions as a shelter and rest, which affects emotional calm, including giving empathy, by listening to complaints, understanding the situation of his wife, taking part in thinking about his wife's problems, caring about his wife's health especially if the wife is sad, worried when his wife is sick, showing affection, trust and attention [12].

\section{Husband's Support in the form of Assessment support}

The results of the study concerning the form of husband support in the form of assessment support found that $63.6 \%$ received husband support in the form of assessment support, while $36.4 \%$ lacked husband support in the form of assessment. According to [12], support for assessment can be in the form of giving appreciation for the work done, providing feedback on the results or achievements achieved and strengthening and elevating feelings of self-esteem and confidence in individual abilities. Individuals assess supportive behavior from the source, so that individuals feel satisfaction, feel cared for, feel respected, feel compassion and feel trusted. The husband's assessment support for his wife such as understanding the wife's current situation, giving praise to the work of the wife, appreciating the sacrifice of the wife who already contains her baby and accepting any advice given by the wife.

\section{Husband Support in the form of Instrumental support}

The form of husband support in the form of instrumental support found that $69.7 \%$ received husband support in the form of instrumental support, while $30.3 \%$ lacked husband support in the form of instrumental support. Instrumental support is shown in the availability of means to facilitate behavior to help people who face material problems in the form of providing opportunities and time opportunities. Instrumental support can be in the form of material support such as services, goods and financial. Husband's instrumental support for his wife such as helping with homework, providing funds to check his wife's pregnancy, paying attention to the type of food consumed by his wife and delivering his wife to buy baby equipment later [12].

\section{E. Husband Support in the form of information support}

Husband support in the form of information support obtained from this study showed that $54.5 \%$ received husband support in the form of information support, while $45.5 \%$ lacked husband support in the form of information support.

According to the theory from [12], information assistance by helping individuals to find the right alternative for problem solving. Information support can be in the form of advice, advice and guidance from others, so that individuals can overcome and solve problems. Besides that, the information support given by the husband can be in the form of information about pregnancy. The husband can provide reading materials such as books, magazines / tabloids about pregnancy, encourage mothers to check their pregnancy when there are complaints and participate in accompanying the wife to the health worker.

Postnatal mental health for fathers is reported to have various effects on the health of the whole family. Therefore, support for husbands who are accompanying pregnant women is an important issue in the maternal and perinatal health care system. However, resources regarding prenatal delivery education for couples of pregnant women are still limited. The results of this review will provide evidence for prenatal education programs for couples in this case a husband for pregnant women is needed in pregnancy care [15].

One effort to reduce anxiety and cause inner peace and feelings of pleasure in the mother during labor is to provide support from significant people, such as a husband or family [16]. Support the family and the closest people, especially husbands to pregnant women to prepare labor is needed. In this case the husband is very active role in motivating pregnant women to check their pregnancy health workers to get services that are according to standards [11]. The support is in the form of assisting the wife during antenatal visits, giving more attention and affection when the wife is pregnant, providing additional information on important things in caring for pregnancy and providing both financial and transportation facilities to conduct antenatal care. The 
husband's emotional support for his wife can cause inner peace and a happy feeling in his wife, so that the wife finally becomes easy to adjust to the situation of the pregnancy [12].

The results of a study conducted in Boston of two economically and ethnically different groups in the Boston area highlighted higher levels of antenatal anxiety, depression, and smoking among pregnant women who reported that support received during pregnancy from their partners was in the low category. Partner support can be an important target and potentially modified for interventions to improve pregnancy outcomes [17]. The importance of husband or partner support other than during pregnancy and childbirth, for mothers who obtain husband support when it comes to breastfeeding while working mothers reminded 1.48 times the self-efficacy of nursing mothers [18].

\section{CONCLUSION}

Based on the research results obtained from 33 pregnant women, there were $60.6 \%$ received husband support and $39.4 \%$ lacked/less husband support. This shows the need for cross-sectoral cooperation to be able to realize the role of husband and family during the assistance of during pregnancy, childbirth until post-partum for the mother in order to improve the health of the mother and her baby.

\section{ACKNOWLEDGMENT}

We would like to thank Aisyiyah Yogyakarta University and Kalasan Public Health Center for facilitate to this research and be an important part in this study.

\section{REFERENCES}

[1] Romauli, S.. Asuhan Kebidanan 1 Konsep Dasar Asuhan Kehamilan. 1 ed. 2016. Yogyakarta: Buku Beta Yogyakarta.

[2] Janiwarty, B. \& Pieter, H. Pendidikan Psikologi Untuk Bidan. 2012, Medan: Rapha Publishing.

[3] WHO. World Health Statistics 2017: Monitoring Health For The SDGs, s.l.: World Health Organization.

[4] Ministry of Health Indonesia (Kementrian Kesehatan RI,) 2017. Profil Kesehatan Indonesia.

[5] Agustina, R.. Faktor-Faktor Yang Berhubungan Dengan Persiapan Persalinan Pada Ibu Hamil Di Puskesmas Kasihan I Kabupaten Bantul Yogyakarta, 2017, Universitas 'Aisyiyah Yogyakarta: Skripsi.
[6] Nevid, J. S. Psikologi Konsepsi dan Aplikasi. 2017. Bandung: Nua Media.

[7] Notoatmodjo, S. Metodologi Penelitian Kesehatan. 2018. Jakarta: Rineka Cipta.

[8] Widiarti, F. Hubungan Dukungan Suami dengan Kecemasan Ibu hamil Trimester III Dalam Menghadapi Persalinan Di BPS Istri Utami Sleman. 2017. Universitas 'Aisyiyah Yogyakarta: Skripsi.

[9] Pomerantz, A. M. Psikologi Klinis Ilmu Pengetahuan, Praktik, dan Budaya. 3 ed. 2014. Yogyakarta: Pustaka Pelajar.

[10] Kalisa, Richard., Malande., Oliver Ombea. Birth preparedness, complication readiness and male partner involvement for obstetric emergencies in rural Rwanda. Pan Afr Med J . 2016 Oct 17;25:91.doi: 10.11604/pamj.2016.25.91.9710. eCollection 2016. https://pubmed.ncbi.nlm.nih.gov/28292054/ Diakses tanggal 10 Juli 2020

[11] Sumiati. Faktor-Faktor Yang Mempengaruhi Kesiapan Ibu Hamil Dalam Menghadapi Persalinan Di ruang Bersalin Rumah Sakit Umum Labuang Baji Makassar. Jurnal Ilmiah Kesehatan Diagnosis, Volume 5, p. 6. 2015.

[12] Fithrianty. Pengaruh Karakteristik Ibu dan Dukungan Suami terhadap Pemeriksaan Kehamilan di Kecamatan Kuta Cot Glie Kabupaten Aceh Besar. Kesehatan Keperawatan, pp. 40-42. 2011

[13] M.M, Friedman. Buku Ajar Keperawatan Keluarga: Riset, Teori, Dan Praktik. 2010. Jakarta: EGC.

[14] Rukiah, A. Y., Yulianti, L., Maemunah \& Susilawati, L.,. Asuhan Kebidanan II Persalinan. 2 ed. 2009. Jakarta: Trans Info Media.

[15] Suto, Maiko., Takahare., Kenji., Yamane, Yumina., Ota., Erika. Effects of prenatal childbirth education for partners of pregnant women on paternal postnatal mental health: a systematic review and meta-analysis protocol. Meta-Analysis Syst Rev . 2016 Feb 3;5:21. doi: $\quad 10.1186 / \mathrm{s} 13643-\quad 016-0199-3$. https://pubmed.ncbi.nlm.nih.gov/26841924/. Diakses tanggal 10 Juli 2020

[16] Mahmudah, H. Peran Suami Dalam Memberikan Dukungan Moril Persiapan Persalinan Di Puskesmas Pleret Bantul. Media Ilmu Kesehatan, Volume I, pp. 47-52. 2016

[17] Cheng, Erika R. Shiman, Sheryl L Rifas., Perkins., Meghan E. Edwards, Janjet Wilson Rich., Glman, Matthew w., Wright, Rosalind., Taveras., Elsie M. 2016. The Influence of Antenatal Partner Support on Pregnancy Outcomes. J Womens Health (Larchmt) . $2016 \quad$ Jul;25(7):672-9. doi: 10.1089/jwh.2015.5462. Epub $2016 \quad$ Feb 1. https://pubmed.ncbi.nlm.nih.gov/26828630/. Diakses Tanggal 10 Juli 2020

[18] Kurniati, Nurul. Dukungan Suami terhadap Self Efficacy Ibu Menyusui Bekerja di Puskesmas Jetis Yogyakarta. Jurnal Terapan Keperawatan Poltekkes Malang. 2(1), .pp. 28- 35. 2016. 